International Journal of Agriculture, Environment and Bioresearch

Vol. 4, No. 04; 2019

ISSN: $2456-8643$

\title{
COMPARATIVE ANALYSIS OF MORPHOLOGICAL AND CHEMICAL VARIABILITY IN DIFFERENT FENNEL (FOENICULUM VULGARE MILL.) CULTIVARS
}

\author{
* Fatma Kalleli ${ }^{1,2}$, Ines Bettaieb Rebey ${ }^{3}$, Nesrine Razgallah ${ }^{1,2}$, Moufida Saidani Tounsi ${ }^{3}$, Mahmoud \\ M'Hamdi' ${ }^{1,2}$ \\ ${ }^{1}$ Horticultural Science Laboratory,National Agronomic Institute of Tunisia. University of Carthage, Tunisia \\ 2Université de Sousse, Institut Supérieur Agronomique de Chott Meriem, 4042, Sousse, Tunisie, \\ ${ }^{3}$ Laboratory of Medicinal and Aromatic PlantsBiotechnology Center of Borj-Cedria BP 901, 2050, Hammam-Lif, \\ Tunisia.
}

\author{
http://doi.org/10.35410/IJAEB.2019.4418
}

\begin{abstract}
Knowledge on phenotypic and chemical diversity among fennel (Foeniculum vulgare Mill.) cultivars is a milestone in the improvement of this specie which is considered as one of the most important medicinal plants. For this purpose, the present study was conducted in order to compare for the first time fennel cultivars regarding their agro-morphological traits as well as their essential oil yield and composition. Ten fennel cutivars were cultivated in a randomized completely block design whereas the seeds essential oil was analysed by GC-MS analysis. All phenotypic traits showed variation among the cultivars examined. Correlations between traits showed a significant positive relation between yield and height, number of leaves, number of branches, number of umbels, number of umbellate and peduncle length. Significant genotypic variations were also observed in essential oil content and composition in which trans-anethole, estragole, fenchone and limonene were the main constituents. Clustering method classified the ten fennel cultivars into 3 major groups. Moreover, PCA analysis showed great dispersion of these cultivars. The diversity identified in this study, especially from the three varietal types, showed that some cultivars are featured with several agro-morphological and chemical characteristics and could be further exploited as promising material for the creation of new varieties.
\end{abstract}

Keywords: Agro-morphological traits, essential oils, Foeniculum vulgare Mill.

\section{INTRODUCTION}

Fennel (Foeniculum vulgar Mill.) is one of the oldest aromatic and medicinal plants of the Apiaceae family which is native of southern Europe and the Mediterranean region [1] but it has wild growing in France, Spain, Portugal, and North Africa. Nevertheless, fennel is mainly cultivated in India, Japan, China, Brazil, Argentina and Turkey [2] _ [3]. Botanically, there are three fennel varieties: bitter fennel (Foeniculum vulgare Mill. Subsp. vulgare var. vulgare), sweet fennel (Foeniculum vulgare subsp. vulgare var. dulce) and fennel bulb (Foeniculum vulgare subsp. vulgare var. azoricum) [4] _ [5]. In fact, all parts of the plant (bulbs, leaves, stalks, and 
seeds) are edible and the fresh leaves and dried seeds were most commonly used as culinary ingredients. Besides, fennel seeds are used as flavoring agents in food products such as well as an ingredient of cosmetics and pharmaceutical products [6]. Numerous researches have shown that fennel seed essential oil has valuable antioxidant, antidiabetic, antibacterial and antifungal activities [7] _ [8]. Moreover, fennel has been shown to possess antispasmodic, diuretic, antiinflammatory, analgesic, secretomotor, secretolytic and galactagogue properties [9] _ [7] _ [10]. Genetic variation in plants can be estimated by such varied tools as morphological, chemical and molecular markers. While morphological variation can be highly affected by the local conditions of the collection site [11], chemical variation is a robust tool for medicinal plants caracterisation in relation to their morphological traits [12]. Furthermore, the importance of fennel as a medicinal and spice plant involved the need to improve some of its agronomical characteristics, such as early ripening, larger or smaller fruits, limited growth height, higher essential oil yield and resistance to fungal diseases [13] _ [14] _ [15]. Accordingly, the importance of the genetic wealth for the development of improved fennel varieties is undeniable and requires backup action to reduce the effects of genetic erosion. Knowledge of the genetic diversity in the germplasm populations is important for the efficient germplasm management and long-term breeding programs [16] _ [17]. Based on the above considerations, the present was designed to compare fennel cultivars regarding their agro-morphological traits and essential oil composition and to find the relationships likely to exist between morphological traits and essential oil constituents. Such information would be important to indicate the effect of geographic origin on agro-morphological and biochemical traits of fennel seed cultivars. Promising fennel cultivars can be used in various breeding programs and have the potential of enhancing its utilization.

\section{MATERIALS AND METHODS}

\subsection{Plant material}

Ten fennel seed cultivars were used in this study. Seven cultivars were collected from the field in the principal production regions of fennel in Tunisia. This collection was completed by the acquisition of plant material from two regions of France (Villeneuve La Garenne and Marseille), and a registered variety (Doux de Florence). The cultivars collected belong to the three variety types of fennel. Thus, the Bizerte, Korba and Jerba cultivars belong to the var. Dulce; The Somaa, Kairouan and Dar Chaabène cultivars belong to the var. Azoricum and the Sfax, Marseille and Villeneuve cultivars belong to the var. vulgare.

Table1. Origin of Foeniculum vulgare cultivars included in this study with their respective geographic coordinates and altitude.

\begin{tabular}{|c|ccccc|}
\hline \multirow{2}{*}{ Origin } & Provenance & Code & Longitude (E) & Latitude (N) & Altitude (m) \\
\hline & Korba & KOR & 10.86 & 35.58 & 15 \\
\cline { 2 - 6 } & Dar chaabène & DAR & 10.75 & 36.47 & 183 \\
\cline { 2 - 6 } & Somaa & SOM & 10.78 & 36.54 & 134 \\
\hline & Bizerte & BIZ & 10.03 & 37.16 & 5 \\
\hline
\end{tabular}


International Journal of Agriculture, Environment and Bioresearch

Vol. 4, No. 04; 2019

ISSN: $2456-8643$

\begin{tabular}{|c|ccccc|}
\hline \multirow{3}{*}{ Tunisia } & Sfax & SFA & 10.76 & 34.74 & 8 \\
\cline { 2 - 6 } & Kairouan & KAI & 10.09 & 35.67 & 65 \\
\cline { 2 - 6 } & Djerba & JER & 10.84 & 33.80 & 6 \\
\hline \multirow{3}{*}{ France } & Marseille & MAR & 5.36 & 43.29 & 28 \\
\cline { 2 - 6 } & Villeneuve LG & VIL & 2.32 & 48.93 & 27 \\
\hline
\end{tabular}

\subsection{Morphological traits}

The field experiment was conducted in the experimental farm of the Higher Agronomic Institute of Chott Mariem (Sousse, Tunisia), latitude $35^{\circ} 38^{\prime} \mathrm{N}$, longitude $10^{\circ} 33^{\prime} \mathrm{E}$ and altitude $36 \mathrm{~m}$. The site was characterized by a semi-arid climate with a mean annual precipitation of $230 \mathrm{~mm}$ and an average temperature of $18.5^{\circ} \mathrm{C}$. The soil had salty-sandy texture. The experiment was carried out using a complete random blocks with three replications. Plantlets were transplanted on October 2015 with row spacing of $0.80 \mathrm{~m}$ and by respecting a density of 4 plants $/ \mathrm{m}^{2}$. Each cultivars sown area was of $15 \mathrm{~m}^{2}(5 \mathrm{~m} \times 3 \mathrm{~m})$. Fertilization consisted of 50 units of nitrogen as ammonium nitrate brought twice during the crop cycle. The drip irrigation was carried out one to twice frequencies per week. Harvest was on June 2016. Seeds harvested were air-dried and stored at 4 ${ }^{\circ} \mathrm{C}$ until use for further analysis.

For each fennel cultivar, measurements were recorded on the following agro-morphological traits: plant height $(\mathrm{cm})$, number of leaves per plant, number of branches per plant, leaves length $(\mathrm{cm})$, petiole length $(\mathrm{cm})$, cotyledons length $(\mathrm{mm})$, stem diameter $(\mathrm{mm})$ aerial and root biomasses (\%).Additionally, Flowering and yielding parameters such as the umbels number per plant, umbellets (umbellules) per umbel, Peduncle length $(\mathrm{cm})$, Diameter of the main umbel $(\mathrm{mm})$, fruiting rate $(\%)$, seed yield/plant $(\mathrm{g})$ and 1000 seed weight $(\mathrm{g})$ were determined at the end of the experiment. These quantitative traits were investigated on the basis of the fennel descriptors developed by the International Union for the Protection of New Varieties of Plants [18] and were determined on ten randomly selected plants from the center rows of each cultivar in each replication.

\subsection{Essential oil extraction}

Essential oil of fennel seeds was extracted according to the method of Bettaieb Rebey et al. [19]. Whole air-dried seeds $(50 \mathrm{~g})$ were subjected to hydrodistillation for $180 \mathrm{~min}$ using a Clevengertype apparatus. The oils obtained were stored at $-20^{\circ} \mathrm{C}$ prior to analysis.

\subsection{Gas Chromatography-Mass Spectrometry (GC-MS) analysis}

GC-MS analysis was performed on a gas chromatograph HP 5890 (II) interfaced with a HP 5972 mass spectrometer with electron impact ionization $(70 \mathrm{eV})$. A HP-5MS capillary column (30 m x $0.25 \mathrm{mmoL}, 0.25 \mu \mathrm{m}$ film thickness) was used. 


\subsection{Compounds identification}

Essential oil components were identified by matching their recorded mass spectra with those stored in the Wiley 09 NIST 2011 mass spectral library of the GC-MS data system and other published mass spectra [20]. Relative percentage amounts of the identified compounds were obtained from the electronic integration of the peak areas without the use of the correction factor.

\subsection{Statistical Analyses}

Data were subjected to statistical analysis using "XL STAT 2007" statistical program package. One-way analysis of variance (ANOVA) followed by Duncan's multiple range tests at the significance level of 5\% was used to compare means, a two-tail correlation analysis was performed to estimate quantitative relationships among the traits. Chemical and morphological variability were assessed using linear regression, principal component analysis (PCA) and Hierarchical cluster (HCA).

\section{RESULTS AND DISCUSSION}

\subsection{Morphological variation}

\subsubsection{Analysis of variance}

The summary of 16 morpho-agronomic traits recorded from the 10 fennel cultivars are presented in Table 2 and 3.

As can be seen in Table 2, significant differences were observed between the studied cultivars for growth parameters. However, cultivars of the type vulgare (Marseille, Sfax and Villeneuve) exhibited the higher plant height $(188.87 \mathrm{~cm})$, cotyledons length $(3.42 \mathrm{~mm})$, leaf length $(36.25$ $\mathrm{cm})$, cotyledons length $(3.41 \mathrm{~mm})$ and the number of leaves per plant (43.63) in comparison to the cultivars of the two other types. The highest aerial dry matter was accumulated by the Jerba cultivar (24\%) whereas the highest root part was accumulated by the cultivar Dar Chaabène $(36.29 \%)$. Besides, vulgare cultivars presented significantly the higher number of branches (11.24) in comparison to dulce and azoricum ones (7.21).

Based on our experimental results, it was shown that vulgare fennel cultivars were characterized by the highest values of flowering parameters when compared to the azoricum and dulce ones (Table 3). Indeed, the Tunisian cultivar from Sfax showed the higher number of umbels per plant (147.71), number of umbellate per umbel (33.86), peduncle length $(26.95 \mathrm{~cm})$ and diameter of the main umbel $(17.76 \mathrm{~mm})$. On the other hand, the cultivar Jerba belonging to the type dulce exhibited the higher fruiting rate $(79.62 \%)$. The number of umbellate per umbel of the experimented fennel cultivars belonging to dulce and azoricum variety types ranged between 13.76 and 24.38. The corresponding value for peduncle length of the ten fennel cultivars ranged between 11.38 and 26.95 .

Moreover, the cultivar Villeneuve showed the significantly and remarkably higher seed yield per plant $(108.29 \mathrm{~g})$ whereas, the lower one was observed in the registered variety "Doux de Florence" (19.38g). On the other hand, the highest 1000 seed weights were observed in azoricum 


\section{International Journal of Agriculture, Environment and Bioresearch}

Vol. 4, No. 04; 2019

ISSN: $2456-8643$

and dulce fennel cultivars and were ranged between 4.9 and 5.14g. However, the cultivars Marseille, Sfax and Villeneuve showed the lowest 1000 seed weights (4.24 - 4.43g).

All the considered characters showed significant differences $(\mathrm{P}<0.01)$ indicating the presence of a high level of heterogeneity in collected materials from different regions. Such a high variability in fennel was in agreement with the results obtained by Singh et al. [21], Patel et al. [22], Meena et al. [23], Sengupta et al. [24]. The major agro-morphological variation observed was probably due to the influence of environmental factors and multigenic traits.

Table 2. Plant growth parameters of different fennel (Foeniculum vulgare Mill.) cultivars.

\begin{tabular}{|c|c|c|c|c|c|c|c|c|c|}
\hline Cultivar & $\begin{array}{c}\text { Plant } \\
\text { height }(\mathrm{cm})\end{array}$ & $\begin{array}{c}\text { Number of } \\
\text { leaves per } \\
\text { plant }\end{array}$ & $\begin{array}{c}\text { Number of } \\
\text { branches per } \\
\text { plant }\end{array}$ & $\begin{array}{l}\text { Leaf length } \\
(\mathrm{cm})\end{array}$ & $\begin{array}{c}\text { Stem } \\
\text { diameter } \\
(\mathrm{mm})\end{array}$ & $\begin{array}{c}\text { Petiole } \\
\text { length }(\mathrm{mm})\end{array}$ & $\begin{array}{l}\text { Cotyledons } \\
\text { length }(\mathrm{mm})\end{array}$ & $\begin{array}{l}\text { Aerial dry } \\
\text { matter }(\%)\end{array}$ & $\begin{array}{l}\text { Root dry } \\
\text { matter }(\%)\end{array}$ \\
\hline BIZ & $141.4 \pm 6.26^{d}$ & $20.9 \pm 1.97^{c}$ & $7.9 \pm 1.179^{\mathrm{d}}$ & $20.87 \pm 5.51^{\mathrm{i}}$ & $2.02 \pm 0.08^{d}$ & $1.95 \pm 0.22^{\mathrm{f}}$ & $1.79 \pm 0.3^{\mathrm{d}}$ & $18.8 \pm 1.26^{\mathrm{d}}$ & $13.27 \pm 1.44^{\mathrm{e}}$ \\
\hline DAR & $97.9 \pm 4.44^{\mathrm{h}}$ & $15.5 \pm 1.75^{d}$ & $7.05 \pm 1.024^{\mathrm{c}}$ & $27.73 \pm 2.02^{f}$ & $4.44 \pm 0.17^{c}$ & $3.89 \pm 0.35^{\text {cd }}$ & $2.72 \pm 0.35^{\mathrm{c}}$ & $20.27 \pm 0.46^{c}$ & $36.29 \pm 0.65^{a}$ \\
\hline JER & $115.1 \pm 9.2^{\mathrm{e}}$ & $20.33 \pm 1.49^{c}$ & $7.14 \pm 1.014^{\mathrm{d}}$ & $23.99 \pm 1.41^{\mathrm{h}}$ & $2.3 \pm 0.17^{d}$ & $2.72 \pm 0.26^{f}$ & $1.65 \pm 0.33^{d}$ & $24 \pm 2.42^{a}$ & $25.31 \pm 3.08^{b}$ \\
\hline$\overline{\text { KAI }}$ & $103.1 \pm 4.45^{g}$ & $15.3 \pm 1.11^{\mathrm{d}}$ & $6.48 \pm 0.873^{c}$ & $26.32 \pm 1.27^{g}$ & $4.44 \pm 0.5^{\mathrm{c}}$ & $4.52 \pm 0.27^{\mathrm{cd}}$ & $2.92 \pm 0.37^{c}$ & $20.73 \pm 1.16^{c}$ & $15.96 \pm 1.46^{\mathrm{d}}$ \\
\hline KOR & $109.1 \pm 6.57^{f}$ & $20.86 \pm 5.79^{c}$ & $7.24 \pm 0.99^{d}$ & $23.21 \pm 5.81^{\mathrm{h}}$ & $3.77 \pm 1.68^{\mathrm{d}}$ & $2.04 \pm 0.96^{\mathrm{e}}$ & $1.23 \pm 0.23^{\mathrm{e}}$ & $23.2 \pm 0.56^{\mathrm{ab}}$ & $13.68 \pm 0.74^{\mathrm{e}}$ \\
\hline$\overline{\text { MAR }}$ & $163.8 \pm 17.23^{c}$ & $42.8 \pm 2.24^{b}$ & $11.14 \pm 1.19^{b}$ & $34.71 \pm 2.45^{\mathrm{c}}$ & $5.97 \pm 0.13^{b}$ & $1.06 \pm 0.19^{b}$ & $3.38 \pm 0.37^{b}$ & $10.67 \pm 0.62^{f}$ & $18.14 \pm 0.42^{c}$ \\
\hline SFA & $226.3 \pm 5.29^{\mathrm{a}}$ & $41.8 \pm 3.03^{b}$ & $11.05 \pm 1.02^{b}$ & $37.74 \pm 2.61^{\mathrm{a}}$ & $4.63 \pm 0.54^{b}$ & $2.71 \pm 0.64^{\mathrm{c}}$ & $3.61 \pm 0.61^{\mathrm{a}}$ & $12.87 \pm 0.35^{\mathrm{e}}$ & $16.3 \pm 0.55^{\mathrm{d}}$ \\
\hline SOM & $103.3 \pm 3.47^{g}$ & $15.9 \pm 1.71^{\mathrm{d}}$ & $6.57 \pm 0.926^{\mathrm{c}}$ & $28.96 \pm 2.17^{\mathrm{e}}$ & $4.16 \pm 0.41^{\mathrm{c}}$ & $3.79 \pm 0.32^{\mathrm{de}}$ & $2.88 \pm 0.32^{\mathrm{c}}$ & $12 \pm 0.38^{\mathrm{e}}$ & $13.47 \pm 5.94^{\mathrm{e}}$ \\
\hline$\overline{\mathrm{DOU}}$ & $95.8 \pm 3.24^{\mathrm{h}}$ & $16.1 \pm 1.38^{\mathrm{d}}$ & $8.1 \pm 0.768^{c}$ & $30.58 \pm 3.68^{d}$ & $4.17 \pm 0.51^{\mathrm{c}}$ & $4.46 \pm 0.42^{\mathrm{de}}$ & $1.75 \pm 0.43^{\mathrm{d}}$ & $22.67 \pm 2.5^{b}$ & $15.62 \pm 1.13^{\mathrm{d}}$ \\
\hline VIL & $176.4 \pm 6.9^{b}$ & $46.19 \pm 4.97^{\mathrm{a}}$ & $11.52 \pm 0.87^{\mathrm{a}}$ & $36.3 \pm 3.08^{b}$ & $6.57 \pm 0.44^{\mathrm{a}}$ & $1.23 \pm 0.35^{\mathrm{a}}$ & $3.25 \pm 0.27^{b}$ & $11.93 \pm 0.26^{\mathrm{e}}$ & $17.31 \pm 0.9^{\text {cd }}$ \\
\hline Mean & 133.25 & 25.60 & 8.42 & 29.04 & 4.24 & 2.83 & 2.52 & 17.71 & 18.53 \\
\hline SD & 2.89 & 0.856 & 0.148 & 0.255 & 0.101 & 0.089 & 0.061 & 0.422 & 0.584 \\
\hline Max & 235.00 & 50 & 12 & 45 & 7 & 5 & 5 & 30 & 37 \\
\hline Min & 89.00 & 12 & 6 & 14 & 2 & 0 & 1 & 10 & 3 \\
\hline $\mathrm{CV}(\%)$ & 31.43 & 48.46 & 25.49 & 22.03 & 34.54 & 45.66 & 34.82 & 29.17 & 38.61 \\
\hline
\end{tabular}

Values followed by different superscripts $(\mathrm{a}-\mathrm{f})$ in the lines are significantly different at $\mathrm{p}<0.05$ (means of the replicates). 


\section{International Journal of Agriculture, Environment and Bioresearch}

Vol. 4, No. 04; 2019

ISSN: 2456-8643

Table 3. Seed yield and its components of Tunisian and French fennel (Foeniculum vulgare Mill.) cultivars.

\begin{tabular}{|c|c|c|c|c|c|c|c|}
\hline Cultivar & $\begin{array}{c}\text { Number of umbels } \\
\text { per plant }\end{array}$ & $\begin{array}{c}\text { Number of } \\
\text { umbellets per } \\
\text { umbel }\end{array}$ & $\begin{array}{l}\text { Peduncle length } \\
(\mathrm{cm})\end{array}$ & $\begin{array}{l}\text { Diameter of the } \\
\text { main umbel }(\mathrm{mm})\end{array}$ & Fruiting rate $(\%)$ & $\begin{array}{l}\text { Seed yield per } \\
\text { plant }(\mathrm{g})\end{array}$ & $\begin{array}{c}1000 \text { seed weight } \\
(\mathrm{g})\end{array}$ \\
\hline BIZ & $66.57 \pm 5.19^{d}$ & $24.24 \pm 3.75^{\mathrm{c}}$ & $15.9 \pm 0.94^{\text {cd }}$ & $10 \pm 0.84^{\mathrm{f}}$ & $60.25 \pm 6.61^{\text {bed }}$ & $69.29 \pm 13.64^{b}$ & $4.9 \pm 0.3^{b}$ \\
\hline DAR & $25.1 \pm 3.99^{f}$ & $18.38 \pm 3.28^{\mathrm{d}}$ & $12.95 \pm 1.02^{\mathrm{de}}$ & $14.24 \pm 0.83^{\mathrm{c}}$ & $50.42 \pm 16.9^{\mathrm{e}}$ & $24.71 \pm 3.8^{\mathrm{de}}$ & $5 \pm 0^{\mathrm{ab}}$ \\
\hline JER & $38.38 \pm 5.06^{\mathrm{e}}$ & $17.24 \pm 1.51^{\mathrm{d}}$ & $18.33 \pm 0.66^{c}$ & $10.19 \pm 0.87^{f}$ & $79.62 \pm 13.4^{\mathrm{a}}$ & $54.48 \pm 10.4^{\mathrm{c}}$ & $4.95 \pm 0.22^{\mathrm{ab}}$ \\
\hline KAI & $20.67 \pm 2.59^{g}$ & $14.1 \pm 1.61^{\mathrm{e}}$ & $11.38 \pm 0.5^{\mathrm{e}}$ & $13.43 \pm 0.87^{\mathrm{d}}$ & $51.45 \pm 21.92^{\mathrm{de}}$ & $21.14 \pm 3^{\mathrm{ef}}$ & $5 \pm 0^{\mathrm{ab}}$ \\
\hline KOR & $39.62 \pm 5.44^{\mathrm{e}}$ & $24.38 \pm 5.23^{c}$ & $20 \pm 1.22^{\mathrm{bc}}$ & $12.14 \pm 0.85^{\mathrm{e}}$ & $78.67 \pm 11.71^{\mathrm{a}}$ & $51.1 \pm 3.86^{\mathrm{c}}$ & $4.95 \pm 0.22^{\mathrm{ab}}$ \\
\hline MAR & $137.33 \pm 8.5^{\mathrm{c}}$ & $33.67 \pm 2.37^{\mathrm{a}}$ & $26.81 \pm 0.87^{a}$ & $17.48 \pm 0.81^{\mathrm{a}}$ & $64.10 \pm 2.58^{\mathrm{bc}}$ & $108.29 \pm 6.44^{\mathrm{a}}$ & $4.24 \pm 0.44^{\mathrm{c}}$ \\
\hline SFA & $147.71 \pm 1.55^{\mathrm{a}}$ & $33.86 \pm 6.7^{\mathrm{a}}$ & $26.95 \pm 1.02^{\mathrm{a}}$ & $17.76 \pm 0.94^{\mathrm{a}}$ & $66.96 \pm 4.01^{\mathrm{b}}$ & $107.57 \pm 1.47^{\mathrm{a}}$ & $4.33 \pm 0.48^{c}$ \\
\hline SOM & $27.76 \pm 2.66^{\mathrm{f}}$ & $13.76 \pm 1.26^{\mathrm{e}}$ & $12.43 \pm 0.81^{\mathrm{de}}$ & $15.19 \pm 1.44^{\mathrm{b}}$ & $55.30 \pm 18.03^{\mathrm{cde}}$ & $27.86 \pm 2.95^{\mathrm{d}}$ & $5 \pm 0^{\mathrm{ab}}$ \\
\hline $\mathrm{DOU}$ & $20.19 \pm 1.94^{g}$ & $14.14 \pm 1.15^{\mathrm{e}}$ & $17.38 \pm 0.91^{\mathrm{c}}$ & $14.48 \pm 0.6^{c}$ & $67.12 \pm 19.76^{b}$ & $19.38 \pm 1.28^{\mathrm{f}}$ & $5.14 \pm 0.36^{\mathrm{a}}$ \\
\hline VIL & $143.52 \pm 6.35^{b}$ & $28 \pm 4.79^{\mathrm{b}}$ & $22.86 \pm 0.91^{\mathrm{ab}}$ & $15.24 \pm 1.04^{\mathrm{b}}$ & $66.87 \pm 5.46^{\mathrm{b}}$ & $107.1 \pm 5.35^{\mathrm{a}}$ & $4.43 \pm 0.51^{\mathrm{c}}$ \\
\hline Mean & 66.68 & 22.17 & 18.5 & 14.01 & 64.07 & 59.09 & 4.50 \\
\hline SD & 3.577 & 0.570 & 0.578 & 0.186 & 1.141 & 2.478 & 0.061 \\
\hline Max & 154 & 40 & 107 & 19 & 115 & 119 & 31 \\
\hline Min & 16 & 7 & 9 & 9 & 21 & 16 & 2 \\
\hline $\mathrm{CV}(\%)$ & 77.72 & 37.21 & 45.28 & 19.19 & 25.80 & 60.77 & 34.07 \\
\hline
\end{tabular}

Values followed by different superscripts $(\mathrm{a}-\mathrm{g})$ in the lines are significantly different at $\mathrm{p}<0.05$ (means of the replicates). 
International Journal of Agriculture, Environment and Bioresearch

Vol. 4, No. 04; 2019

ISSN: $2456-8643$

\subsubsection{Correlations between agro-morphological traits of fennel cultivars}

Phenotypic correlations between 16 agro-morphological traits are shown in Table 4. Highly significant positive correlations were recorded between the number of umbels, the height, the number of leaves, the number of branches and the number of umbellates, as well as between the length of the leaves and the diameter of the main umbel. On the contrary, grain yield had a strong negative correlation $(\mathrm{P}<0.05)$ with petiole length $(-0.86)$ and aerial dry matter $(-0.64)$. The 1000 seeds weight was strongly negatively correlated with the number of leaves, the number of branches, the number of umbellates and the yield of seeds.

Seed yield was positively correlated with height, number of leaves, number of branches, number of umbels, number of umbellate and peduncle length. These traits are considered major components for seed yield. Therefore, these characters must be considered when selecting for improved fennel yield. These results are consistent with the results of Garg et al. [25] for plant height and number of branches / plant and Singh \& Mittal [21] for plant height and number of seeds per umbel. In fennel, Sefidan et al. [26], and Zahid et al. [27] also revealed a positive and significant correlation between the number of umbels and seed yield. In the study by Yadav et al. [28] seed yield was positively correlated with number of umbels / umbels, number of branches, height of plant and number of umbels. Piccaglia \& Marotti [29] characterized different fennel cultivars based on morphological and agronomic traits and found positive correlations between the number of umbels / plant and the weight of plants. The estimate correlation coefficient suggests a strong inherent association between the characters studied. Furthermore, correlation analysis suggests that some traits could be used to predict the other. Traits that show significant positive correlation might be improved simultaneously.

Table 4. Correlation coefficients between agro-morphological traits in fennel cultivars.

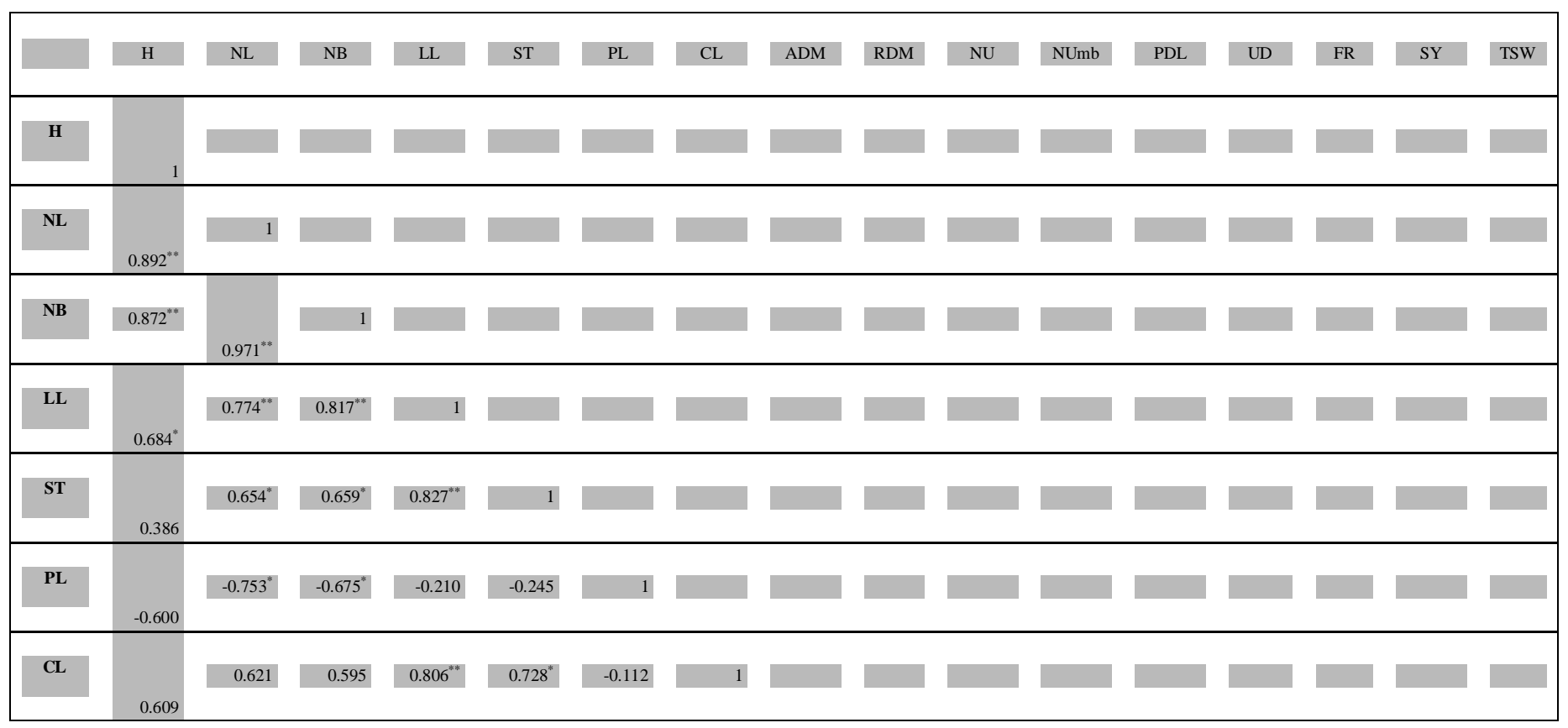




\section{International Journal of Agriculture, Environment and Bioresearch}

Vol. 4, No. 04; 2019

ISSN: $2456-8643$

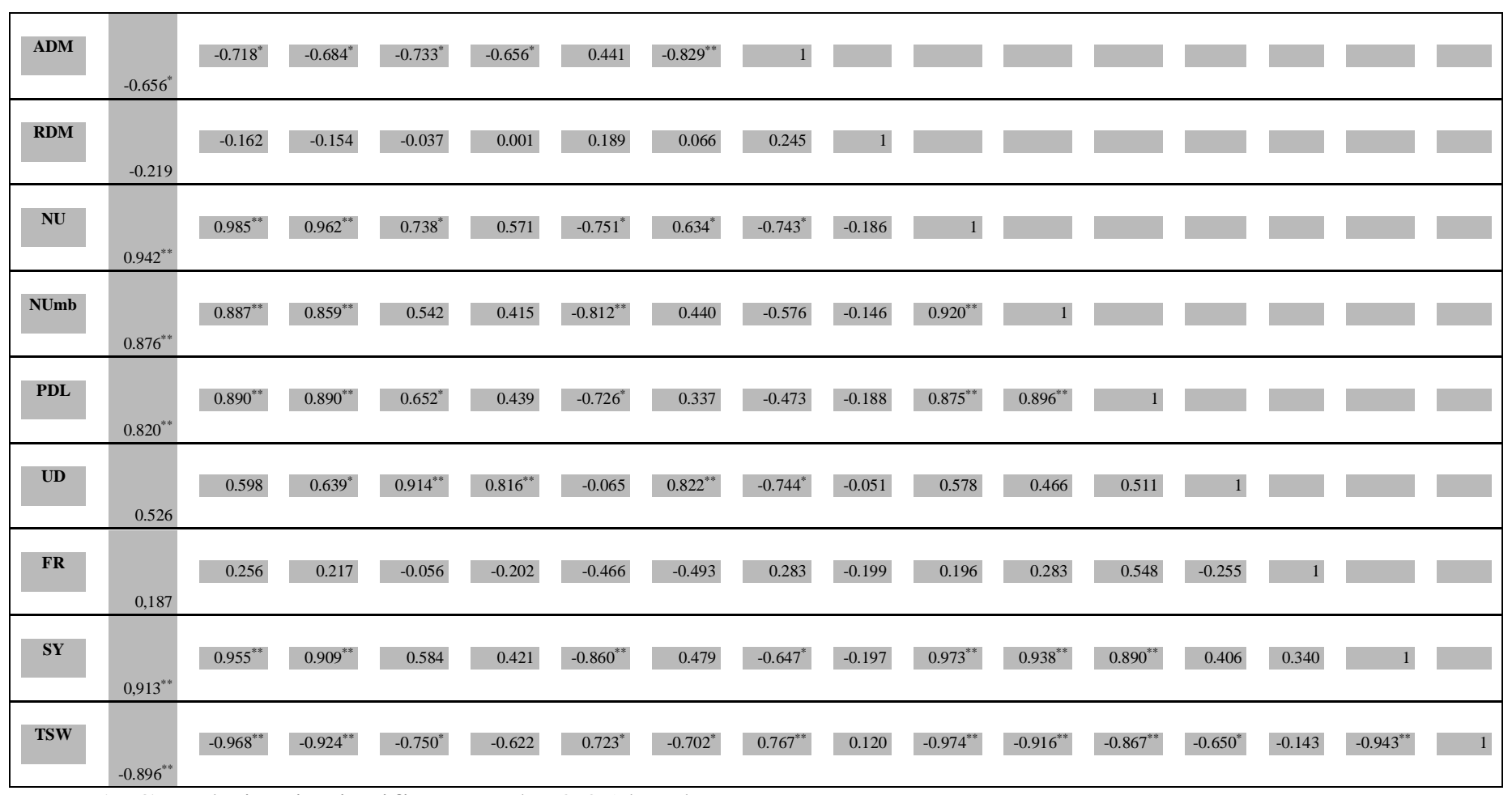

*, Correlation is significant at the 0.05 level

**, Correlation is significant at the 0.01 level

H :Plant height, NL: Number of leaves per plant, NB: Number of branches per plant, LL: Leaf length, SD: Stem diameter, PL: Petiole length, CL: Cotyledons length, ADM: Aerial dry matter, RDM: Root dry matter, NU: Number of umbels per plant, Numb: Number of umbellets per umbel, PDL: Peduncle length, DU: Diameter of the main umbel, FR: Fruiting rate, SY: Seed yield per plant, TSW: 1000 seed weight.

Table 5: Multiple linear regressions (stepwise) explaining essential oil yield variation as a dependent variable, and all the growth traits as independent variables among ten fennel cultivars. Levels of significance: $* * * \mathbf{P}<0.001$; $* \mathbf{P}<0.05$; ns not significant

\begin{tabular}{|c|c|c|c|}
\hline Dependent variable & Variable chosen & $\mathrm{R}^{2}$ & Sig \\
\hline & RDM & 0.785 & *** \\
\hline & RDM-ADM & 0.994 & *** \\
\hline
\end{tabular}

\subsubsection{Clustering of the cultivars}

The dendrogram obtained was presented in figure 1. Results perfectly revealed the existence of a significant level of inter-ecotype agro-morphological polymorphism. Cluster analysis of morphological traits using mean values of 16 characteristics by UPGMA method in fennel 
divided populations into three main groups. The first cluster composed of Azoricum fennel cultivars: Dar Chaabène, Kairouan, Somaa and the control, the second cluster consisted of the dulce fennel cultivars (Korba, Jerba and Bizerte), while bitter fennel introduced from Villeneuve and Marseille and the Sfax cultivar formed the third cluster. Populations in a cluster are more genetically similar than the counterparts in other cluster groups [30]. Results don't show any relationship between geographical coordinates (altitude, latitude and longitude) and the groups obtained. Indeed, Dar Chaabène and Somaa collected at an altitude $(183 \mathrm{~m}$ and $134 \mathrm{~m})$ are grouped together with the Kairouan cultivar collected at an altitude $(65 \mathrm{~m})$, the Jerba cultivar collected at an altitude $(6 \mathrm{~m})$ is grouped with the cultivar Korba collected at altitude $(15 \mathrm{~m})$ and the Bizerte cultivar collected at an altitude $(5 \mathrm{~m})$. Thus, the cultivars Korba, Somaa and Dar chaabene belonging to the same region belong to different groups. In the same context, Lopes et al. [31] grouped different accessions of fennel into different groups that are not related to the geographical coordinates of the collection regions. This could be related to the exchange of cultivars occuring among peasants from different localities [32].

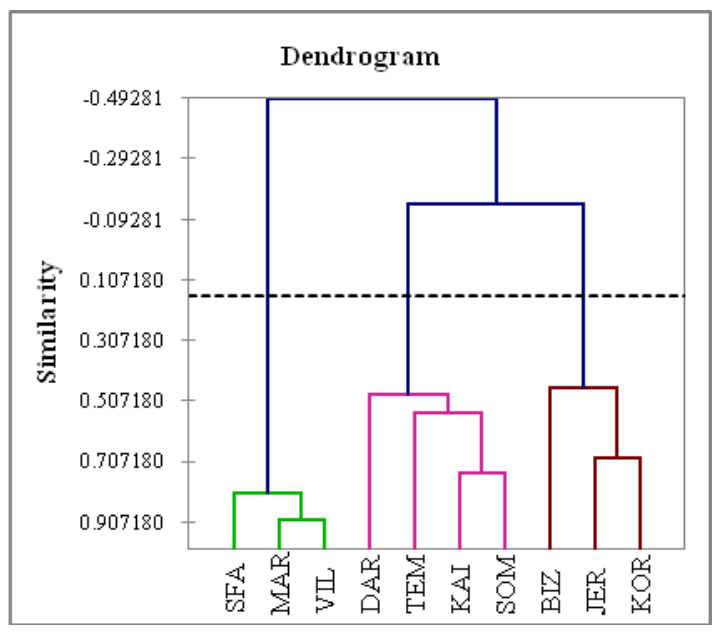

Fig. 1: Dendrogram of fennel cultivars obtained by cluster analysis of morphological traits based on average taxonomic distance between groups using the unweighted pair-group method with arithmetic average (UPGMA).

\subsubsection{Principal components of morphological characters}

The principal components analysis (PCA) performed with morphological data for (Foeniculum vulgare Mill) (Fig.2). The PCA analysis explained, by two factors, $85.09 \%$ of the cumulative variance. The first factor explains $67.26 \%$ and the second factor explains $17.83 \%$. The analysis showed 4 main groups. The first group was formed by leaf length, cotyledon length, stem diameter and diameter of the main umbel. The second group was formed by petiole length, root dry matter content and thousand seed weight. This group is diametrically opposed to the third axis which is formed by the aerial dry matter rate. While the rest of the parameters constitute the fourth group formed by the height, the number of leaves, the number of branches, the length of the peduncle, the number of umbels, the number of umbellules, the rate of fruiting as well as the 
seed yield. The PCA (Fig.2), based on morphological characters, allowed to distinguish three cultivar groups. The Somaa, Dar Chaabène, Kairouan and Doux de Florence cultivars were characterized by longer leaf petioles, the highest root dry matter content, and the highest thousand-seed weight. The Bizerte, Korba and Jerba cultivars were characterized by the highest aerial dry matter content. Moreover, maximum values of the other traits were recorded for the Marseille, Villeneuve and Sfax cultivars. According to Veronesi \& Falcinelli [33], Information obtained by PCA analysis can assist breeders to distinguish the number of highly differentiated cultivars for use in crossing and selection for breeding successful program. So, genotypes of this later group might be good parents to be used in improvement programs of fennel.

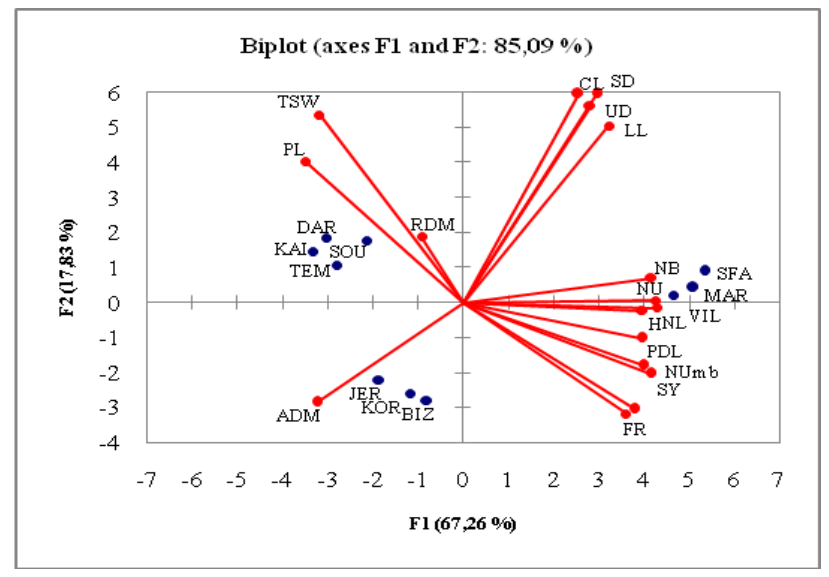

Fig. 2. Distribution of the 10 fennel cultivars for the morphological traits in the plan of axes 1 and 2.

H :Plant height, NL: Number of leaves per plant, NB: Number of branches per plant, LL: Leaf length, ST: Stem diameter, PL: Petiole length, CL: Cotyledons length, ADM: Aerial dry matter, RDM: Root dry matter, NU: Number of umbels per plant, Numb: Number of umbellets per umbel, PDL: Peduncle length, DU/ Diameter of the main umbel, FR: Fruiting rate, SY: Seed yield per plant, TSW: 1000 seed weight.

\subsection{Chemical variation}

\subsubsection{Essential oil yield}

All the Fennel seed samples studied afforded yellowish oils with aromatic spicy odour. Essential oil yield variability was clear in all samples studied. Since the cultivars were cultivated under the same pedo-climatic and cultural conditions and these essential oils were isolated and analyzed under the same operating conditions. The oil yield based on dry weight ranged from 2.22 to $5.25 \%(\mathrm{w} / \mathrm{w})$. The highest essential oil yield belonged to the samples taken from "Bizerte" $(5.25 \%)$ while the lowest was recorded for Azoricum fennel cultivars (2.22-3.06\%) (Figure 3).

The oil yield percent obtained in this study is higher than previously reported in the literature. Abu El Nasr et al. [34] showed that the production of essential oils varied with the cultivation year and the fennel variety $(0.82$ - 2.92). While Aprotosoaie et al. [35] who studied the 
production of fennel seed essential oil grown in Romania showed a large variation in volatile oil content from year to year (2.0 to $12.6 \%)$. The extraction yield of essential oil of fennel is very important $(2.81 \%)$ in the essential oil of Pakistani fennel seeds found by Anwar et al. [36]. Mimica-Dukic et al. [37] determined that the distillation method significantly affected the yield of essential oil obtained from fennel seeds $(2.82-3.38 \%)$.

A multiple linear regression (stepwise procedure) was performed to explain essential oil yield variation as the dependent variable. All morpholoical traits measured in fennel cultivars were used as independent variables (Table 5). In this analysis, aerial and root dry weight remained in the final model and were considered as the effective components on the essential oil yield. Other variables related to agro-morphological traits, were not chosen by the model in none of the cases. In fact, they showed a week and non-significant correlation to essential oil yield (data not shown). R2 value of the model indicated that more than $99 \%$ of the total variations of grain yield were justified by these traits. Table 5 showed that regression coefficients of these two traits are significantly positive. So, Increase in their values will lead to increase in the grain yield. Root dry matter was the first variable selected by the model. It alone accounted for around $78 \%$ of the variability in essential oil yield, followed by aerial dry matter as second determinant components, with a minor role in accounting for the differences in essential oil yield. This relationship between morphological and chemical information is important for the valorization of plant genetic resources, namely for breeding of commercially important varieties. Contrary to our results of the relation between the yield in essential oils and the morphological traits, Lal [38] and Safaei et al. [39] reported a positive and significant correlation between essential oil content and grain yield of fennel. Also, Singh et al. [40] and Zahid et al. [27] showed that there was a positive and significant correlation between number of umbel and harvest index with grain yield. Dwivedi et al. [41] reported that there is a positive and significant correlation between grain yield and umber of seed per umbel. Lopes et al. [31] showed a high correlation between fennel oil yield and umbel diameter, umbels number, fruits weight from mature umbels harvested/plant and the average weight of 100 seeds / plant.

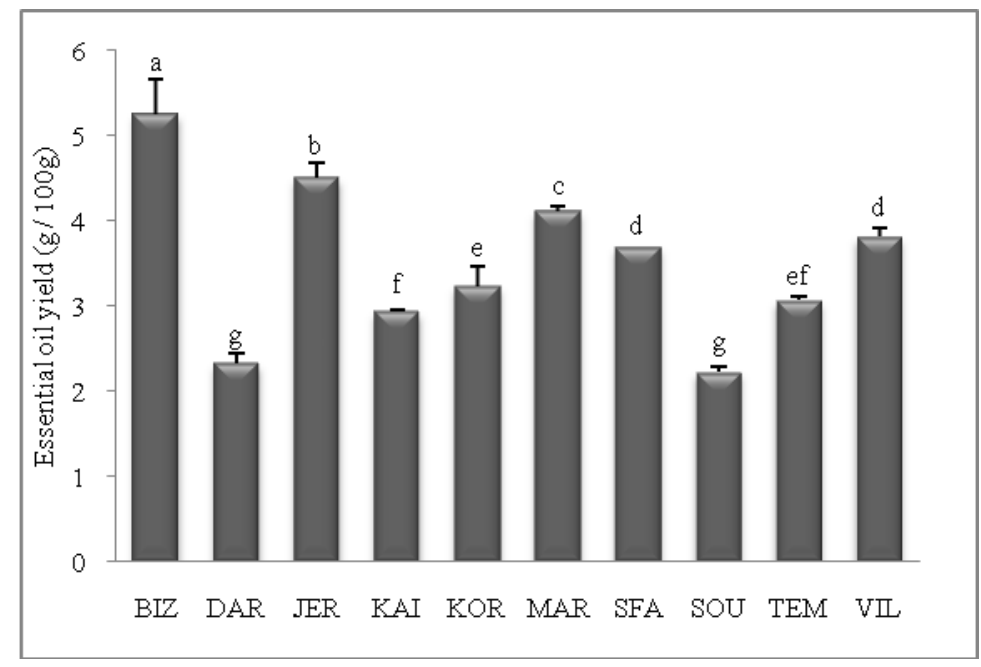


Fig. 3: Seed essential oil yield of different fennel (Foeniculum vulgare Mill.) cultivars. Values are mean of three replicates. Mean values followed by different letters are significantly different at $\mathrm{p}<0.05$.

\subsubsection{Fennel chemotypes based on their major components}

Results revealed a high chemical polymorphism among the ten fennel cultivars. The major compounds detected in these cultivars were Trans -Anethole, Estragole, L-Fenchone and Limonene. Table 4 reports the major compounds of the essential oils from the studied cultivars. Clearly, Azoricum cultivars recorded the highest Trans - Anethole content $(93.33 \%-94.55 \%)$. Bitter fennel cultivars had the highest Estragole $(44.66 \%-88.92 \%)$ and Limonene $(5.65 \%$ $6.22 \%)$ contents, while the highest L-Fenchone content $(10.64 \%-12.09 \%)$ was recorded for sweet fennel. Since, technical and environmental parameters effects were considered negligeable in this study; the obtained variability seems likely to be closely due to genotype. Telci et al. [42] also reported that the fennel essential oil variation can be related to the geographical origins and ecological situations related to climatic conditions of the growing localities.

Table 6: major essential oil compounds (\%) of different fennel (Foeniculum vulgare Mill.) seed cultivars.

\begin{tabular}{|c|c|c|c|c|c|c|c|c|c|c|c|c|}
\hline Compound & $\mathbf{R I}^{\mathbf{a}}$ & $\mathbf{R I}^{\mathbf{b}}$ & BIZ & JER & KOR & MAR & VIL & SFA & KAI & SOM & DAR & DOU \\
\hline Limonene & 1206 & 1030 & $4.67^{\mathrm{c}}$ & $4.64^{c}$ & $3.88^{\mathrm{d}}$ & $5.65^{\mathrm{b}}$ & $6.32^{\mathrm{a}}$ & $6.22^{\mathrm{a}}$ & $2.36^{\mathrm{e}}$ & $2.86^{\mathrm{e}}$ & $2.44^{\mathrm{e}}$ & $3.00^{\mathrm{e}}$ \\
\hline L-Fenchone & 1402 & 1072 & $11.01^{\mathrm{b}}$ & $12.09^{a}$ & $10.64^{b}$ & $2.82^{\mathrm{e}}$ & $9.47^{\mathrm{c}}$ & $9.37^{\mathrm{c}}$ & $2.86^{\mathrm{d}}$ & $2.21^{\mathrm{d}}$ & $2.76^{d}$ & $2.00^{\mathrm{d}}$ \\
\hline Estragole & 1688 & 1196 & $7.62^{\mathrm{d}}$ & $17.06^{c}$ & $4.67^{\mathrm{e}}$ & $88.92^{\mathrm{a}}$ & $44.72^{b}$ & $44.66^{b}$ & $0.14^{\mathrm{h}}$ & $1.12^{\mathrm{fg}}$ & $0.48^{\mathrm{gh}}$ & $1.66^{\mathrm{f}}$ \\
\hline $\begin{array}{c}\text { Trans - } \\
\text { Anethole }\end{array}$ & 1654 & 1297 & $74.88^{\mathrm{c}}$ & $63.41^{\mathrm{d}}$ & $78.26^{b}$ & $0.14^{f}$ & $36.31^{\mathrm{e}}$ & $36.17^{\mathrm{e}}$ & $94.55^{\mathrm{a}}$ & $93.70^{\mathrm{a}}$ & $94.21^{\mathrm{a}}$ & 93.33 \\
\hline
\end{tabular}

Values are mean of three replicates \pm SD. Mean values in a row with different letters are significantly different at $\mathrm{P}<0.05$

\subsubsection{Clustering of the cultivars based on Biochemical Characteristic}

The cultivars examined in this study were investigated to determine the likely compositional similarities among their essential oils. For this purpose, HCA and PCA were carried out using a data matrix consisting of 10 cultivars $* 4$ major components. HCA performed by UPGMA method revealed variability among the studied cultivars, which led to the classification of the cultivars into three groups (Fig. 4). The first group (cluster I) consisted of the three cultivars of Bizerte, Jerba and Korba. The second group (cluster П) comprising Kairouan, Somaa, Dar Chaabène and Doux de Florence. ClusterW comprised three cultivars Sfax,Villeneuve and Marseille. Based on these major compounds and their levels, the essential oils were classified into the following two chemotypes: chemovariety Trans-anethole (clusters I and II) and chemovariety Estragole (cluster III). 
Vol. 4, No. 04; 2019

ISSN: $2456-8643$

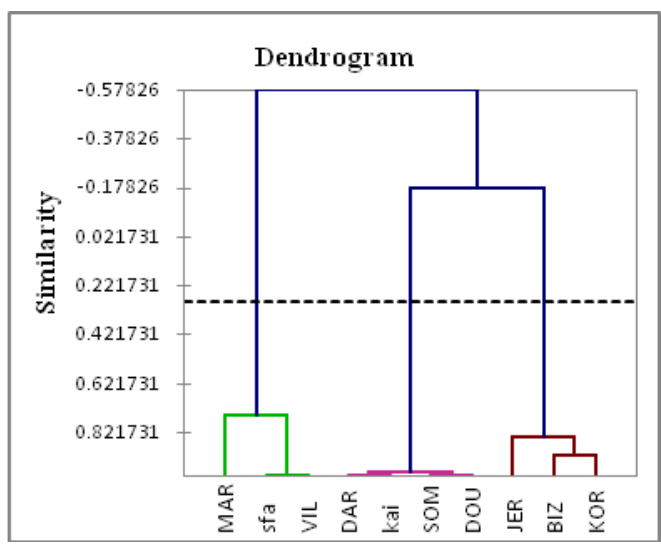

Fig. 4: Dendrogram of fennel cultivars obtained by cluster analysis of essential oil major compounds based on average taxonomic distance between groups using the unweighted pairgroup method with arithmetic average (UPGMA).

\subsubsection{Principal Component Analysis of Biochemical Characteristics}

To simplify the multidimensional dataset, the major compounds data was subjected to PCA. PC1 and PC2 explained $72.63 \%$ and $26.15 \%$, respectively, of the total variance in the percentages of essential oil percents. Together, the first two PCs accounted for $98.78 \%$ of the total variance. PCA analysis classified more precisely the studied cultivars on the basis of the major compounds essential oil. The first group assembled Bizerte, Jerba and Korba, all rich in Trans-anethole with considerable percentages in L-Fechone. The second group composed by Dar Chaabène, Somaa, Kairouan and Doux de Florence contained high levels of Trans-anethole. A third group composed by Sfax and Villeneuve. The essential oil composition of these cultivars was marked by significant levels of Estragole but which were exceptionally followed by relatively high levels of Trans- anethole, which is not the case in the fourth group formed only by the Marseille cultivar, whose composition in essential oil is dominated only by Estragole.

The resulting chemical clusters were similar from the clusters obtained by morphological characterization. The compounds Trans anethole, Estragole, L-fenchone and Limonene were found in greater amount, which defined the formation of three clusters, according to the cluster analysis that was confirmed by PCA analysis. These compounds were also identified as major compounds in several studies with fennel seeds [43] _ [40] _ [35]. Considering that Transanethole was characterized by antithrombotic action due to its antiplatelet activity, its destabilizing effect and its vaso-relaxing action [44], the essential oils of the plants of the first and second clusters may have potential biological activity. The same occurs to the essential oils of the plants of the third cluster, since they present high amounts of Estragole having already proven their antibacterial activity [45]. 


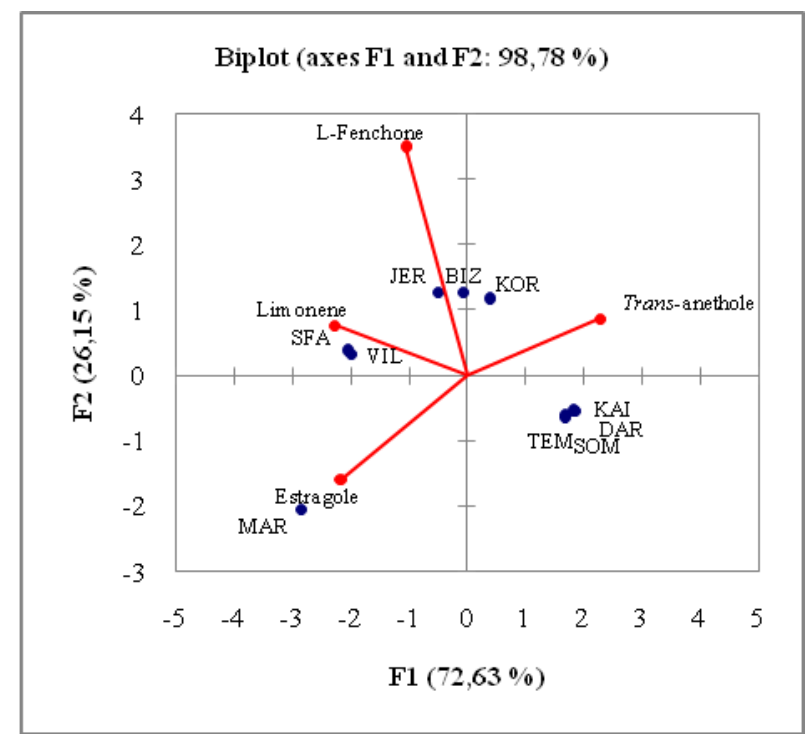

Fig. 5. Distribution of the 10 fennel cultivars for the essential oil major compounds in the plan of axes 1 and 2 .

\section{CONCLUSION}

The obtained results reported a high variation among the ten cultivars of fennel as evidenced by the morphological and chemical characterization which clearly distinguished the cultivars from the three subspecies. Correlations between major morphological traits are positive and significant with seed yield. The main constituents were detected to be estragole, trans-anethole, L-fenchone and limonene. Clustering method and PCA analysis was effective in categorizing populations into diverse groups based on 16 agro-morphological traits and major essential oil compounds. Therefore, data presented in this study allowed the identification of cultivars with distinct characteristics. They could be also used to select advantageous adaptive traits for crosses in the breeding programs and to improve adaptation to the Tunisian environment. This study recommends consolidating of morphological and chemical characterization with the use of molecular markers for fennel germplasm characterization and genetic diversity since they are under little influence from the environment.

\section{REFERENCES}

[1] Miraldi, E. (1999). Comparison of the essential oils from ten Foeniculum vulgare Miller samples of fruits of different origin. Flavour and Fragrance Journal, 14, 379-382.

[2] Omidbaigi, R. (2009). Production and Processing of Medicinal Plants. Astan Quds Publication, Iran, Mashhad. 87P.

[3] Amir-Timuri, S., Shamshadi, K., \& Khaliliyan, S. (2012). Iran's position in the fennel exporting: Comparative advantage of export approach. Agricultural Economics Research, 3, 97 83. 
[4] Badoc, A., Lamarti, A., Bourgeois, G., Garde, J.P., \& Deffieux,G.(1995). Hybridation intraspécifique chez le fenouil (Foeniculum vulgare Mill.). Bull. Soc. Pharm. Bordeaux, 134, 107-126.

[5] Napoli, E. M., Curcuruto, G., \& Ruberto, G. (2010). Screening the essential oil composition of wild Sicilian fennel. Biochemical Systematics and Ecology, 38, 213-223.

[6] Abou El-Nasr, T.H.S., Ibrahim, M.M., Aboud, K.A., \& Al-Kordy, M.A.A. (2013). Genetic variation among three fennel (Foeniculum vulgare Mill.) varieties on the basis of morphological characters, essential oil composition and ISSR markers. Journal of Applied Sciences Research, 9(3), 1594-1603.

[7] Lucinewton, S., Raul, N., Carvalho, J., Mirian, B., Lin, C., \& Angela A. (2005). Supercritical fluid extraction from fennel (Foeniculum vulgare), global yield, composition and kinetic data. Journal of Supercritical Fluid ,35, 212-219.

[8] El-Soud, N.A., El-Laithy, N., El-Saeed, G., Wahby, M.S., Khalil, M., Morsyn F., \& Shaffie, N. (2011). Antidiabetic activities of Foeniculum vulgare Mill. essential oil in Streptozotocin-induced diabetic rats. Macedonian. Journal of Medical Sciences, 15, 139-146.

[9] Iten, F., \& Saller, R. (2004). Fennel tea: risk assessment of the phytogenic monosubstance estragole in comparison to the natural multicomponent mixture. Research in complementary and natural classical medicine, 11, 104-108.

[10] Ebeed, N.M., Abdou, H.S., Booles, H.F., Salah, S.H., Ahmed, E.S., \& Fahmy, K.(2010). Antimutagenic and chemoprevention potentialities of sweet fennel (Foeniculum vulgare Mill.) hot water crude extract. Journal of American Science, 6, 831-842.

[11] Saran, P.L., Tripathy, V., Prasnna Meena, R. \& Kumar, J. (2017). Chemotype characterization and development of morphological markers in Ocimum basilicum L. germplasm. Scientia Horticulturae, 215, 164-171.

[12] Nsuala, B.N., Kamatou, G.P., Sandasi, M., Enslin, G., \& Viljoen, A. (2017). Variation in essential oil composition of Leonotis leonurus, an important medicinal plant in South Africa. Biochemical Systematics and Ecology, 70, 155-161.

[13] Reichardt, I., Pank, F. (1993). Methods and results of breeding a fennel variety (Foeniculum vulgare Mill.) for annual cultivation. Acta Horticulturae, 330, 185-189.

[14] Dashora, A., Sastry, E.V.D., Singh, D., \&Nagda, A.K. (2003). Combining ability analysis in varietal crosses of fennel (Foeniculum vulgare Mill.). Indian Journal of Genetics and Plant Breeding, 63, 89-90.

[15] Pank, F., Schneider, E., \& Krüger, H. (2003). Possibilities and limitations of estragole content reduction of fennel (Foeniculum vulgare Mill.) and its preparations. Journal of Medicinal Spice Plants, 4, 164-172. 
[16] Garzón-Martínez, G.A., Osorio-Guarín, J.A., Delgadillo-Durán, P., Mayorga, F., EncisoRodríguez, F.E., Landsman, D., Marino-Ramirez, L., \& Barrero, L.S. (2015). Genetic diversity and population structure in Physalis peruviana and related taxa based on InDels and SNPs derived from COSII and IRG markers. Plant Gene, 4, 29-37.

[17] Roughani, A., Miri, S.M. , Hassandokht, M.R., Moradi, M.R., \& Abdossi, V. (2018). Agro-morphological study on several accessions of garden cress (Lepidium sativumBrassiaceae) in Iran. Pakistan Journal of Botany, 50(2), 655-660.

[18] UPOV. (2001). Guidelines for the conduct of tests for distinctness, uniformity and stability. Fennel (Foeniculum vulgare Miller). TG/183/3.

[19] Bettaieb Rebey, I. Bourgou, S., Aidi Wannes, W., Hamrouni Selami, I., Saidani Tounsi, M., Marzouk, B., Laure Fauconnier, M., \& Ksouri, R. (2017). Comparative assessment of phytochemical profiles and antioxidant properties of Tunisian and Egyptian anise (Pimpinella anisum L.) seeds. Plant Biosystems, 152, 971-978.

[20] Adams, R.P. (2007). Identification of Essential Oil Components by Gas Chromatography/Mass Spectrometry, 4th edn. Allured Publ. Corp., Carol Stream, IL.

[21] Singh, Y., \& Mittal, P. (2002). Studies on variability, heritability and scope of improvement in fennel (Foeniculum vulgare Mill.). Bioved, 13, 7-9.

[22] Patel, D.G., Patel, P.S., \& Patel, I.D. (2008). Studies on variability of some morphological characters in fennel. Journal of Spices and Aromatic Crops, 19, 29-32.

[23] Meena, R.S., Kakani, R.K., Anwer, M.M., \& Panwar, A. (2010).Variability of some morphological characters in fennel. Indian Journal of Agricultural Sciences, 80, 710-712.

[24] Sengupta, S.K., Verma, B.K., \& Naidu, A.K. (2014). Genetic variability study in fennel (Foeniculum vulgare Mill.). International Science Journal, 1(1), 62-64.

[25] Garg , V . K., Sudhir, S., \& Singh , P. K. (2003). Genetic association in fennel grown on sodic soil. Journal of Spices and Aromatic Crops, 12 (2), 171-173.

[26] Sefidan A Y, Valizadeh, M., Aharizad, S., \& Sabzi, M. (2014). Path analysis of grain yield, some morphological traits and essential contents in different fennel (Foeniculum vulgare Mill.). Journal of Biodiversity and Environmental Sciences, 4(5), 10-15.

[27] Zahid, N.Y., Abbasi, N.A., Hafiz, I.A., \& Ahmad, Z. (2008). Morphological charactereristics and oil contents of fennel (Foeniculum vulgare Mill.) accessions from different regions of Pakistan. Journal of The Chemical Society Of Pakistan, 30(6): 889-895.

[28] Yadav, P.S., Pandey, V.P., \& Yadav, Y. (2013). Variability studies in fennel (Foeniculum vulgare Mill.). Journal of Spices and Aromatic Crops, 22 (2), 203-208.

[29] Piccaglia, M., \& Marotti, M. (2001). Characterization of some Italian types of wild fennel (Foeniculum vulgare Mill.). Journal of Agricultural and Food Chemistry, 49, 239-244. 
[30] Nyadanu, D., Aboagye, L.M., Akromah, R., Osei M.K., \& Ordoe, M.B. (2014). Agromorphological characterisation of Gboma eggplant, an Indigenous fruit and leafy vegetable in Ghana. African Crop Science Journal, 22,281-289.

[31] Lopes, V.R., Barata, A.M., Farias, R., Mendes, M.D., Lima, A.S., Pedro, L.G., Barroso, J.G., \& Figueiredo, A.C. (2010). Morphological and essential oil variability from nine Portuguese fennel (Foeniculum vulgare Miller) accessions. Acta Horticulturae, 860, 33-49.

[32] Salami, H.A., Adjanohoun, A., Padonou, W., Yacoubou, A.M., Aly, D., Yallou, C., Sina H., \& Baba-Moussa, L. (2015). Morphological diversity of corn's (Zea mays L.) local cultivar and improved varieties in central and north of Benin. American Journal of Plant Sciences, 6(18), 2867-2877.

[33] Veronesi, F. \& Falcinelli, M. (1988). Evaluation of an Italian germplasm collection of Festuca arundinacea Schreb. through a multivariate analysis. Euphytica, 38(3): 211-220.

[34] Abou El-Nasr, T.H.S., Ibrahim, M.M., Aboud, K.A., \& Al-Kordy, M.A.A. (2013). Genetic variation among three fennel (Foeniculum vulgare Mill.) varieties on the basis of morphological characters, essential oil composition and ISSR markers. Journal of Applied Sciences Research, 9(3), 1594-1603.

[35] Aprotosoaie, AC., Spac, AD. , Hancianu, M., Miron, A.,. Tanasescu, VF, Dorneanu, V., \& Stanescu, U.(2010). The chemical profile of essential oils obtained from fennel fruits (Foeniculum vulgare Mill.). Farmacia, 58, 46 - 54.

[36] Anwar, F., Ali, M., \& Hussain Shahid, M., (2009). Antioxidant and antimicrobial activities of essential oil and extracts of fennel (Foeniculum vulgare Mill.) seeds from Pakistan. Flavour and Fragrance Journal, 24, 170-176.

[37] Mimica-Dukic, N., Kujundzic, S., Sokovic, M., \& Couladis, M. (2003). Essential oil composition and antifungal activity of Foeniculum vulgare Mill. obtained by different distillation conditions. Phytotherapy Research, 17, 368-371.

[38] Lal, R.K. (2007). Association among agronomic traits and path analysis in fennel. Journal of Sustainable Agriculture, 30, 21-29.

[39] Safaei, L., Zeinali, H., Afiuni, D. (2011). Study of genetic variation of agronomic characteristics in Foeniculum vulgare Mill. genotypes. Iranian Journal of Rangelands and Forests Plant Breeding and Genetic Research, 19, 167-180.

[40] Singh, G., Maurya, S., de Lampasona, M.P., \& Catalan, C. (2005). Chemical constituents, antifungal and antioxidative potential of Foeniculum vulgare volatile oil and its acetone extract. Food Control ,17, 745-752.

[41] Dwivedi, S.V., Sing, T., Mishra, S.K. (2008). Association studies of yield with quantitative and qualitative characters of fennel. Journal of Progressive Horticulture, 40, 114116. 
[42] Telci, I., Bayram, E., Yilmaz, G., \& Avci B. (2006). Variability in essential oil composition of Turkish basils (Ocimun basilicum L.). Biochemical Systematics and Ecology, 34, 489-497.

[43] Ozcan, M., Chalchat, J.C., Arslan, D., Ates, A., \& Ünver, A. (2006). Comparative essential oil composition and antifungal effect of bitter fennel (Foeniculum vulgare subsp. piperitum) fruit oils obtained during different vegetation. Journal of Medicinal Food, 9 (4), $552-$ 561.

[44] Tognolini, M., Ballabeni, V., Bertoni, S., Bruni, R., Impicciatore, M., \& Barocelli, E. (2007). Protective effect of Foeniculum vulgare essential oil and anethole in an experimental model of thrombosis. Pharmacological Research, 56, 254-260.

[45] Moghaddam,, M., Alymanesh,, M.R., Mehdizadeh, , L., Mirzaei, H., , Pirbalouti ; A.G. (2014). Chemical composition and antibacterial activity of essential oil of Ocimum ciliatum, as a new source of methyl chavicol, against ten phytopathogens. Industrial crops and products, 59, 144-148. 